\begin{tabular}{|c|c|}
\hline AUTHORS & $\begin{array}{l}\text { Lyudmyla Shkvarchuk (i) } \\
\text { R } \\
\text { Rostyslav Slav'yuk (i) } \\
\mathbb{R}\end{array}$ \\
\hline ARTICLE INFO & $\begin{array}{l}\text { Lyudmyla Shkvarchuk and Rostyslav Slav'yuk (2021). Households' credit } \\
\text { demand: Main trends and characteristics for Ukraine. Banks and Bank Systems, } \\
\text { 16(3), 13-22. doi:10.21511/bbs.16(3).2021.02 }\end{array}$ \\
\hline DOI & http://dx.doi.org/10.21511/bbs.16(3).2021.02 \\
\hline RELEASED ON & Monday, 02 August 2021 \\
\hline RECEIVED ON & Wednesday, 02 June 2021 \\
\hline ACCEPTED ON & Wednesday, 21 July 2021 \\
\hline LICENSE & $\begin{array}{l}(\mathrm{ccc}) \mathrm{EY} \\
\text { This work is licensed under a Creative Commons Attribution } 4.0 \text { International } \\
\text { License }\end{array}$ \\
\hline JOURNAL & "Banks and Bank Systems" \\
\hline ISSN PRINT & $1816-7403$ \\
\hline ISSN ONLINE & $1991-7074$ \\
\hline PUBLISHER & LLC "Consulting Publishing Company "Business Perspectives" \\
\hline FOUNDER & LLC "Consulting Publishing Company "Business Perspectives" \\
\hline $0^{\circ}$ & $\begin{array}{l}\text { ニニこ } \\
\text { ニこ: }\end{array}$ \\
\hline NUMBER OF REFERENCES & NUMBER OF FIGURES \\
\hline 31 & 2 \\
\hline
\end{tabular}

(c) The author(s) 2021. This publication is an open access article. 


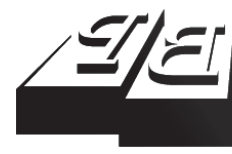

BUSINESS PERSPECTIVES

(O)

LLC "CPC "Business Perspectives"

Hryhorii Skovoroda lane, 10, Sumy, 40022, Ukraine

www.businessperspectives.org
Received on: $2^{\text {nd }}$ of June, 2021 Accepted on: $21^{\text {st }}$ of July, 2021 Published on: $2^{\text {nd }}$ of August, 2021

(C) Lyudmyla Shkvarchuk, Rostyslav Slav'yuk, 2021

Lyudmyla Shkvarchuk, Doctor of Economics, Professor, Department of Finance, Lviv Polytechnic National University, Ukraine. (Corresponding author)

Rostyslav Slav'yuk, Doctor of Economics, Professor, Department of Entrepreneurship, Lviv Polytechnic National University, Ukraine.

\section{HOUSEHOLDS' CREDIT DEMAND: MAIN TRENDS AND CHARACTERISTICS FOR UKRAINE}

\begin{abstract}
Household demand for credits is quite volatile, which requires constant evaluation of it changes. The purpose of the paper is to identify quantitative signals, the use of which increases the predictability of the credit market development. The study utilizes technical analysis methods for an econometric estimation of trends in household demand for credits in Ukraine for the 2002-2019 period. Based on the analysis of historical market lows, it was argued that with all the negative effects of destabilizing factors, the household demand for loans will not fall below the market support point of UAH 50 million. The financial behavior of Ukrainian households when choosing the type of loan is stable and does not change with fluctuations in GDP. Short-term loans are quite dynamic and largely depend on macroeconomic conditions, provoking market movements. If the relevant direction is supported by medium-term loans, the general market trend will correspond to the GDP trend. The demand for long-term loans is quite inertial, its change does not affect the overall market trend. The constant and variable elements of household demand for credit are highlighted.
\end{abstract}

Keywords credit demand, lateral (flat) trend, loan portfolio, market movements, limit of support

JEL Classification $\quad$ D14, G14, G17, G51, E32

\section{INTRODUCTION}

A sound understanding of the processes responsible for shaping credit demand is essential when it comes to developing effective macroeconomic policies in general and monetary policy in particular. Demand for credit is generated by all market participants; each of them operates in the financial market independently, guided by their own financial strategy and tactics. However, there are several unifying themes that drive the decisions of all market participants, which have evolved in response to the unique set of conditions that exist in the financial market and in the economy as a whole. Identifying and defining these conditions is a key task of modern economics. The level of household's credit demand is a crucial variable from the perspective of the broader financial market's development. As noted by Alter et al. (2018), the sustainability of the recent renewed increase in household debt levels worldwide may indeed be an additional cause for concern. The underdevelopment of the financial system is one of the main destabilizing factors of economic growth (Cherkasova et al., 2020). The researchers identify some reasons necessitating the study of households' debt. One of them is the high instability of the financial market associated with the borrowing decision of households. Another reason is that the GDP is sensitive to the households' debt movements. The actions of households on the credit market became one of the reasons for the 2008 financial crisis (Shkvarchuk \& Slav'yuk, 2019). Households use 
the credit market as a buffer to reduce the impact of economic shocks by increasing their borrowings during bad economic times and increasing savings during upturns. Credit also plays an important role in activating the family business (Sági et al., 2020). In addition, households have the option of borrowing money to invest in productive activities that allow them to escape poverty (Kannadas, 2021). The great role of household debt in economic growth necessitates a deeper study of the dynamics of quantitative and qualitative characteristics of the nature of household's credit demand, taking into account the unique set of characteristics that define the current stage of economic development in Ukraine.

In this context, it becomes relevant to determine the trends and characteristics of households' credit demand in Ukraine, as well as identify the quantitative signals, the use of which increases the predictability of the credit market development.

\section{LITERATURE REVIEW}

Research into household credit demand is progressing in several directions. One part of such research has focused directly on the impact of household debt on economic growth. Such studies provide an answer to the question of how household demand changes during the economic cycle. L'opez-Salido et al. (2017) confirm that sentiment in the loanable funds market is a key driver of the cycle, rather than simply a propagation mechanism. Lombardi et al. (2017), using data from 54 economies from 1990 to 2015, have shown that the growth of household loans causes an increase in consumption and GDP growth in the short run, mainly within a 1-year period. One also points to the existence of negative long-term consequences of the growth of household debt, as in the long run, the growth of household loans by $1 \%$ causes a decrease in GDP growth by $0.1 \%$.

Eggertsson and Krugman (2012) suggest that high household debt levels create a supply-constrained economy during recessions. Korinek and Simsek (2016) emphasize the debt-driven demand channel of loanable funds supply shocks for the business cycle.

Kim (2016) provides empirical evidence of business cycles related to household debt by studying the latter's impact on US GDP growth during the 1952-2009 period. The paper distinguishes between the study of economic dynamics in the short and the long term using an autoregressive vector model (VAR) and a vector error correction model (VECM). This shows the existence of a positive two-way feedback loop between aggregate income and short-term household debt. It is noted that in the long run there is a negative link between debt and GDP growth. The study confirms the results of Palley (1994), who investigated the cyclical aspects of consumer borrowing during the various stages of the business cycle. It integrates borrowing into a linear accelerator model and finds that the volume of outstanding loanable funds is a driving force behind economic cycles due to the debt service burden they place on borrowers, leading to a reduction in consumption and production. Dejuán (2017) also discusses the impact of household debt on economic cycles. After analyzing data by country for the 1980-2016 period, the article finds that GDP growth by $1 \%$ leads to a decrease in household debt by $2.44 \%$, an increase in consumption by $5.15 \%$ and an increase in public welfare by $0.48 \%$. Chudik et al. (2015) use the Monte-Carlo simulation method on data from 40 countries for the 1965-2010 period (divided into developed countries and developing countries subgroups) to prove the existence of significant negative long-term effects of debt accumulation, even when accounting for GDP growth.

Studies of the 2008-2009 Great Recession show that the rapid growth of household debt is one of the factors determining the likelihood of a recession. Specifically, Mian and Sufi (2010) argue that the rapid growth of household debt in the largest US states in the years prior to the Great Recession was a key factor responsible to the ensuing economic downturn. In particular, they show that the states that experienced a sharp increase in household debt between 2002 and 2006 subsequently suffered from larger increases in loan repayments and a more severe recession. Glick and Lansing (2010) confirm the findings of Mian and Sufi (2010) using the examples of many other industrialized 
countries. Kane (2020), based on an empirical approach relying on nonlinear autoregression models with smooth transition of vectors (STVAR), uses data for the period 1980-2016 to test the response of the Finnish economy to shocks related to household debt. It is proved that the economic response to shocks associated with household debt is greater during recessions. In particular, a more pronounced impact on consumption is observed.

Another group of scientists turned to the macroeconomic implications of household debt. According to Mian et al. (2017), the increases in household debt are associated with recession and higher unemployment. Duygan-Bump and Grant (2008) argue that household credit has important long-term consequences for all macroeconomics indicators.

Cynamon and Fazzari (2008) observe that the increases in household debt in US in the period 1980-2000 were caused by rising consumption. Alter et al. (2018) argue that there is an optimal limit of lending to households, exceeding which (excess debt) leads to a decrease in consumption in the event of the emergence of adverse economic conditions (exogenous negative shocks).In addition, an increase in household debt leads to an increase in the likelihood of future banking crises, which significantly impairs the effectiveness of financial intermediation and may lead to a wider economic crisis. Santos et al. (2014) argue that the political economy approach is important for the analysis of household debt.

Another line of research on household debt is in the area of behavioral finance. In behavioral finance, the question of whether household borrowing decisions are driven more by objective welfare factors or by subjective psychological factors is hotly contested. Zakaria et al. (2017) suggest that household debt is not a poverty-related phenomenon because the demand for it is driven by subjective "wants" to a larger degree than by objective "needs". Thus, any policy intervention aiming to reduce the average household's debt burden should include educating households on making rational consumption decisions.

Zinman (2014) suggests that a certain disregard for the topic of household debt is evident when compared to similar literature on corporate debt.
Juárez (2015) has developed a household borrowing behavior model. It posits that the borrowing behavior of households not only affects their purchasing power, but also impacts the lending decisions of financial institutions, consequently having a direct impact on the development of both the country's larger economy and household economics in particular (LvGanga et al., 2012).

Modern scientists devote less attention to researching the trends characteristics of households' credit demand. It is well-established that the development of any market is characterized by a sequence of alternating periods of growth and decline. Trends are usually defined as progressive changes of a particular phenomenon over time. The scientists use both qualitative trend analysis and quantitative trendspotting methods to test the market trends. Du and Kamakura (2012) applied a structural dynamic factor-analytic model to analyze trend lines. Villez (2014) proposed using the globally optimal method for such purposes.Pelzer et al., (2001) and Greben (2007) suggested using a nonstationary heterogeneous Markov model to estimate the trends.

To describe the nature of changes over time and the behavior of various phenomena, Brillinger (1995) suggests applying the trend analysis method. Trend analysis has become widely used to assess the dynamics of market prices within the Dow Theory. In a competitive market, demand changes according to the same laws as the price, since the former directly depends on the latter. This gives grounds to apply the methodology of trend analysis to examine and predict the changes in the volume of household debt by using historical volume charts and market statistics. The study is premised on the idea that if financial institutions can identify previous market patterns, they can make fairly accurate predictions of future credit demand. In this study a trend will be taken to refer to the dynamic changes of some quantitative indicators (according to Cuzick, 1988).

The main aims of the paper are to identify the main trends of households' credit demand in Ukraine, to determine the fixed components of the demand and to assess the factors that influence the formation of its variable components. 


\section{METHODOLOGY}

The study is based on the principle of trend analysis and Elliott wave theory. According to the Elliott wave theory, market moves are driven by cyclical waves, with large waves formed by relatively smaller medium waves, which in turn consist of minor small waves. The application of the Elliott wave theory in conjunction with the approach of trend analysis makes it possible to assess the main parameters of household's credit demand and determine their characteristics

Fibonacci number theory is used in the paper to verify the point forecast estimates. "Fibonacci retracement" is a technical analysis tool that is used to determine the best time to buy and sell financial instruments. This technique is based on the Fibonacci sequence (Landau, 2020).

The use of trend analysis in conjunction with regression methods allowed identifying constant and variable elements of household's credit demand. The constant elements of demand are responsible for setting the trend, whereas variable elements strengthen or weaken it. That is, constant elements serve as trend indicators, and variable elements adjust it. Only situations where both elements of household's credit demand are growing simultaneously can jeopardize a country's economic growth, since such situations create an environment conductive to the emergence of crises in the banking sector of the economy.

The identification of market turning points and market support points makes it possible to assess periods of "concern". If lending volumes rise above historical reversals of the upward trend, this should be seen as a determinant of the beginning of a recession in the economy. The rollback of the market to historical lows (support points) is a signal pointing towards the beginning of disintermeditation of financial services. To prevent this, it is necessary to change the policy of lending and financial services.

\section{RESULTS}

Over the past 15 years, household borrowing dynamics in Ukraine has been heterogeneous, with growth periods alternating with periods of significant decline (Figure 1). According to Figure 1, there are three periods of market growth $(G 1, G 2$, $G 3)$, and two periods of decline $(D 1, D 2)$ in the size of the household bank lending market. Therefore, the development of the market of bank lending to households can be described as follows:

$$
G 1 \rightarrow D 1 \rightarrow G 2 \rightarrow D 2 \rightarrow G 3
$$

where $G 1$ is a growth period between the years 2005-2008; D1 - a decline period between 20082009; G2 - a growth period between 2009-2013; D2 - a decline period between 2013-2015; and G3 is a growth period between 2015-2019.

The use of the Elliott wave theory in conjunction with trend analysis gives us grounds to assert that over the past 15 years (2005-2019) the retail bank lending market as a whole has shown a general upward trend (this being the trend's "main wave"). However, this trend was not homogeneous and was accompanied by certain corrective trends (small waves). The value of household's credit demand in 2018 was almost equal to the corresponding value in 2008 (UAH 177,409 and UAH 165,369 million, respectively) (within a $7.02 \%$ margin of error), which confirms the prevalence of a lateral market trend in this period.

There were smaller corrective trends within the overall flat trend: market movements in the direction opposite of the main trend (small waves). That is, these were the periods between 2008-2009 and between 2013-2015. This means that the points of maximum market values in 2008 and 2013 should not be considered as trend turning points (at which the running trend changes direction), and were rather intermediate points (so-called rollback points), when the market temporarily changed its growth trajectory within the bounds of the general flat trend.

To confirm this hypothesis, the Fibonacci theory has been used, which is based on the calculation of the so-called "golden line" (or Golden Ratio). After all, after a temporary rollback, any trend is more likely to persist moving in the same direction it moved in the per-rollback than to turn around. According to the golden ratio, trend rollbacks typically end at one of the following Fibonacci points: 


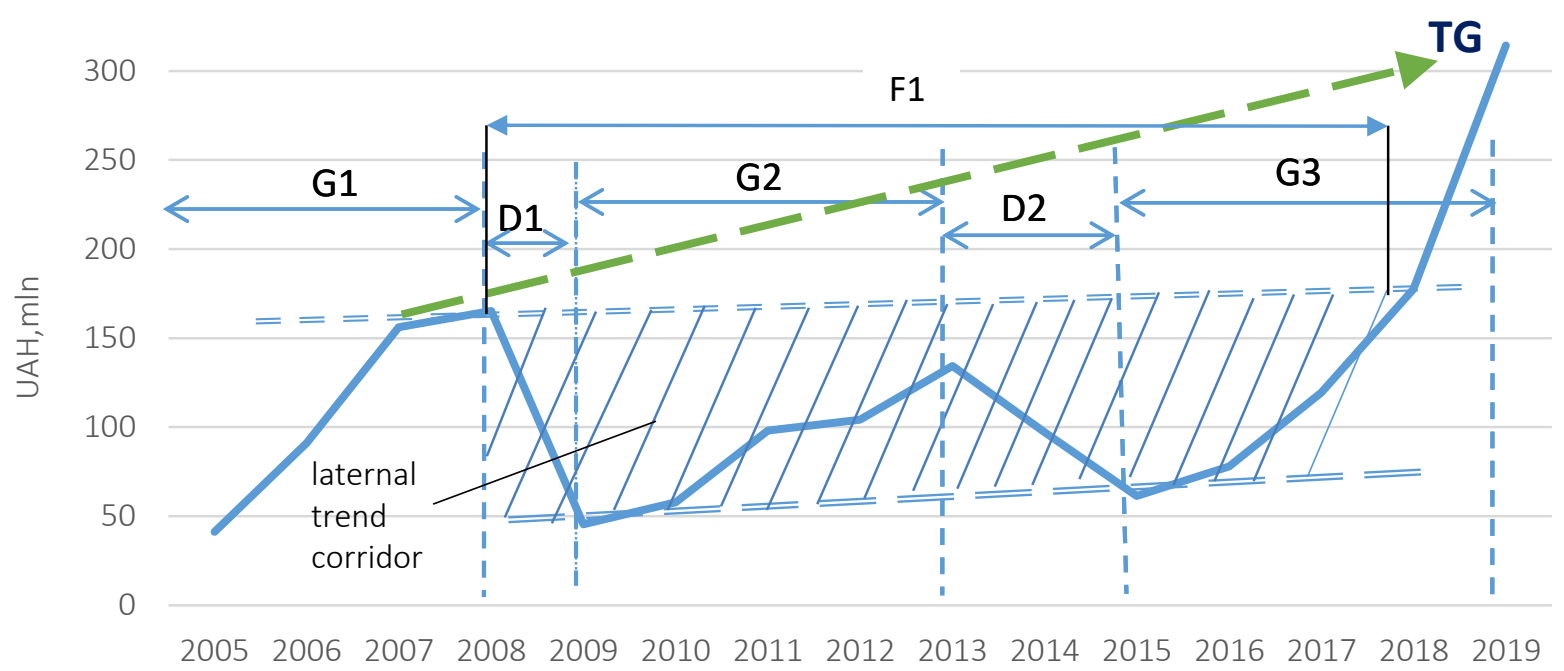

Figure 1. Growth trend of the Ukrainian retail lending market for the period 2005-2019

$38.2 \%, 50.0 \%, 61.8 \%$, etc. The corresponding values of the calculated and actual indicators of the trend of the retail lending market size are presented in Table 1 and Figure 2.

The obtained values (Table 1 and Figure 2) confirm the hypothesis of a general growing trend of the retail lending market in 2005-2019, as well as the existence of smaller corrective trends. The market dynamics fully corresponds to the Elliott wave, as the actual values of the main breakpoints of the trend correspond to the forecasted theoretical values: in $75 \%$ of cases ( 6 out of 8 ), the end of the correction occurred in the range of Fibonacci ratios from the trend wave with accuracy an accuracy of $\mathscr{E}=(0 ; 7.64))$.

The maturity structure of loans was not homogeneous during the analyzed period, but a certain pattern can be traced. The structure of the households' cumulative loan portfolio was mostly dominated by medium-term loans (maturing in 1 to 5 years from the drawdown date) during 10 periods (or $66.67 \%$ of total) within this research horizon.
In $26.67 \%$ of cases (4 periods), short-term loans (maturing within 12 months of the drawdown date) prevailed. However, the direction of the prevailing market trend was mostly determined by the demand for short-term loans (correlation coefficient $\sigma_{s}=0.9012$ ). The trend interdependence of the overall market size and that of mediumterm loans was lower $\left(\sigma_{m}=0.711\right)$. The dynamics of long-term loans did not affect the main market trend $\left(\sigma_{1}=0.238\right)$, although they played a decisive role during the 2007-2009 period. That is, natural fluctuations within the lateral overall trend (during the longer 2008-2018 period) are being caused by changes in demand for short- and mediumterm loans. Household demand for long-term loans during this period can be deemed constant.

The year 2008 signifies the beginning of a new long wave due to significant changes in the behavior of households in the loanable funds market observed at and around this point, namely, a sharp decline in demand for long-term loans. The reversal of the trend in this period determines the point of maximum demand from households for

Table 1. Trend correction point indicators, calculated according to the Fibonacci theory (F) and actual (A)

Source: Authors' elaboration.

\begin{tabular}{|c|c|c|c|c|c|c|c|c|c|c|c|}
\hline Value & $0 \%$ & $23.6 \%$ & $38.2 \%$ & $50.0 \%$ & $61.8 \%$ & $100 \%$ & $138.2 \%$ & $150.0 \%$ & $161.8 \%$ & $200.0 \%$ & 238.2 \\
\hline $\mathrm{F}, \mathrm{UAH} \mathrm{mln}$ & 45.52 & 66.47 & 79.42 & 89.90 & 100.37 & 134.27 & 168.18 & 178.65 & 189.12 & 223.03 & 256.93 \\
\hline A, UAH mln & 45.52 & 61.39 & - & - & 104.10 & 134.27 & 165.37 & 177.41 & - & - & \\
\hline Error coefficient, \% & 0 & 7.64 & - & - & 3.72 & 0 & 1.67 & 0.70 & - & - & - \\
\hline Time point & 2009 & 2015 & - & - & 2012 & 2013 & 2008 & 2018 & - & - & - \\
\hline
\end{tabular}




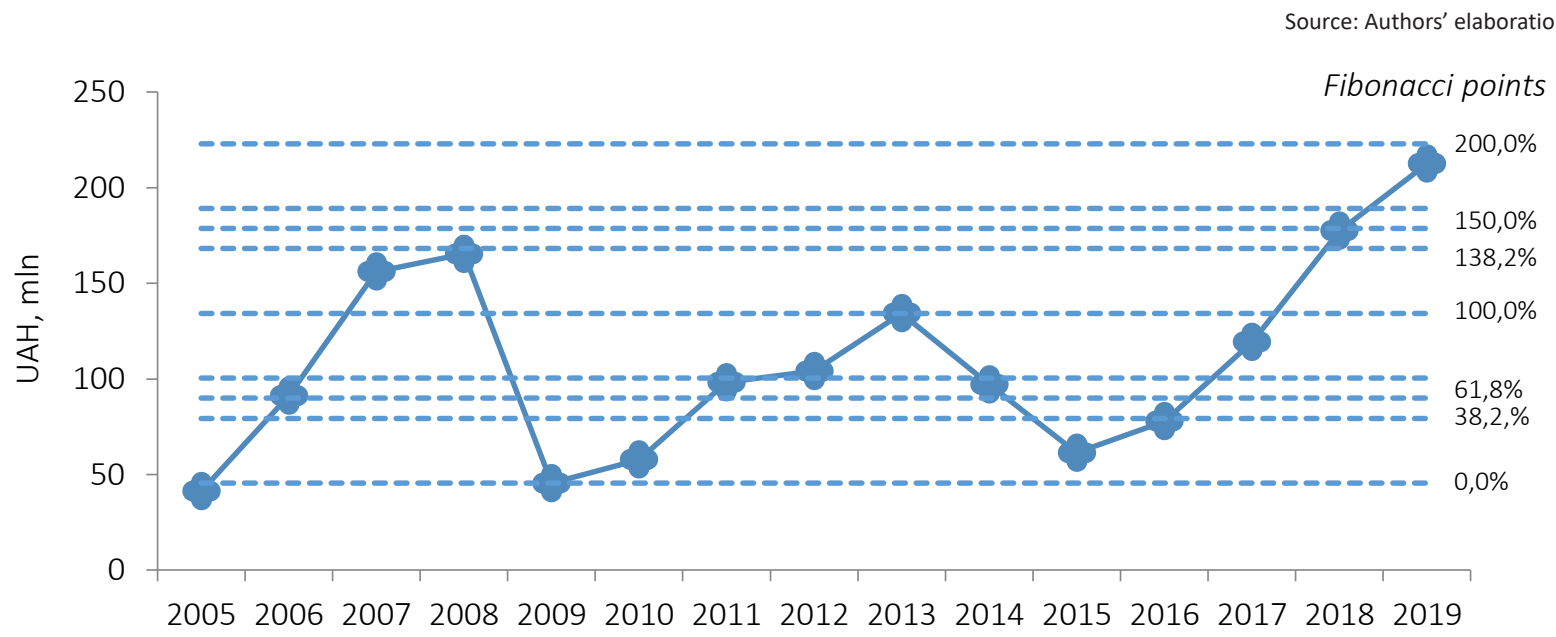

Figure 2. Growth trend of the retail loan market superimposed on the Fibonacci grid chart

long-term loans, which at the time stood at UAH 73,353 million. Achieving levels of demand corresponding to its 2008 level in the near future is unlikely, as it would require not only the existence of a general positive trend in the market, but also a change of priorities in the financial behavior of households. Therefore, this value can be identified as a historical maximum in the market of longterm household lending, and it can be supposed that the market will not return to the staid level during the next long wave.

The volumes of medium- and short-term loans represent the variable elements within the overall demand for credits by households. Therefore, the magnitude of these elements is due to changes in the welfare of borrowers. The preferred repayment period of loans is determined by different needs of households. Short-term loans (up to one year repayment period) are consumer loans aimed at financing current needs. Their predominance in the structure of the household loans portfolio is indicative of a relatively low per capita income, the size of which is often insufficient to cover basic daily needs.

Medium-term household loans are used to cover the cost of purchasing durable goods, whereas long-term loans are used primarily to form a household's long-term asset base (consisting of both personal (movable) property and real estate). The predominance of such loans in the overall market portfolio indicates high current incomes and optimistic future expectations: borrowers are confident that their future income will be of sufficient size to both cover running current expenses and to service long-term debts.

The financial behavior of households in choosing which type of loan to draw is stable and does not change with fluctuations in GDP growth. This hypothesis was confirmed using the $\chi 2$ statistical test formulated as follows:

HO: There is a relationship between the repayment periods of loans drawn by households and the stages of the economic cycle.

The pilot testing parameters are presented in Table 2.

Table 2. Pilot testing parameters of the chisquare of $\mathrm{HO}$

\begin{tabular}{|c|c|c|c|c|}
\hline \multirow{3}{*}{ Category } & \multirow{2}{*}{\multicolumn{2}{|c|}{$\begin{array}{c}\text { Observed } \\
\text { Stages of the } \\
\text { economic cycle }\end{array}$}} & \multirow{2}{*}{\multicolumn{2}{|c|}{$\begin{array}{c}\text { Expected } \\
\text { Stages of the } \\
\text { economic cycle }\end{array}$}} \\
\hline & & & & \\
\hline & Growth & Recession & Growth & Recession \\
\hline $\begin{array}{l}\text { Long-term } \\
\text { loans }\end{array}$ & 1 & 1 & 5 & 3 \\
\hline $\begin{array}{l}\text { Medium-term } \\
\text { loans }\end{array}$ & 8 & 2 & 7 & 7 \\
\hline $\begin{array}{l}\text { Short-term } \\
\text { loans }\end{array}$ & 3 & 0 & 3 & 5 \\
\hline \multicolumn{5}{|l|}{$\chi^{2}=0.0009$} \\
\hline
\end{tabular}

A comparison of the calculated value of Pearson's distance $\chi^{2}$ with the critical value $\chi^{2}$ crit - the largest, which is still considered plausible, compatible with $H O$. The $\chi^{2}$ crit value was determined using 
distribution tables by solving the equation:

$$
P\left(\chi^{2} n>\chi^{2} c r i t\right)=1-\alpha,
$$

where $\alpha$ is the level of significance or "the magnitude of the error of the first kind" (assume a typical value of $\alpha=0.05)$; $n$ is the number of degrees of freedom $(n=2)$.

The critical value is $\chi^{2}$ crit $=5.991$ (at $\alpha=0.05$ and $n=2)$.

The estimated value $\chi^{2}<\chi^{2}$ crit. This means that the null hypothesis is rejected - there is no relationship between the terms of the loans drawn by households and the phase of the economic cycle. In addition, the rather small value of the calculated indicator $\chi^{2}$ indicates that an increase in the number of model parameters was not accompanied by a corresponding decrease in the number of degrees of freedom. This confirms the conclusion about the persistence of household preferences regarding the types of loans received in terms of their period of repayment.

A household's evaluation of its own well-being is directly related to changes in macroeconomic conditions. Based on this, the relationship between household demand for loans and GDP size (as a determinant of the phase of the economic cycle), income growth (as a determinant of welfare), and borrowing costs was assessed.

To form the data of the conjugation table, information was used on the dynamics of the size of Ukraine's GDP in constant prices in the period 2005-2019, household income and the maturity structure of household loans. Based on the data on the dynamics of household loans in Ukraine in 2005-2019, a correlation-regression analysis of the dependence of household demand for loans $(Y)$ was carried out depending on three factors:

- $\mathrm{X}_{1}$ - annual interest rate on loans to individuals, \%;

- $\mathrm{X}_{2}$ - annual GDP in constant prices, UAH mln;

- $\mathrm{X}_{3}$ - annual household income, UAH mln.
The resulting regression equation is as follows:

$$
\begin{aligned}
& Y=186,371.44-6,853.81 X_{1}+ \\
& +0.19 X_{2}-0.11 X_{3} .
\end{aligned}
$$

Checking the overall quality of the multiple regression equation using Fisher's test (F-statistic) showed that the regression equation is statistically reliable (i.e., the coefficients $b_{i}$ are jointly significant).

The estimated value of $F=9.35$.

Tabular value for degrees of freedom $k_{1}=3$ and $k_{2}$ $=n-m-1=15-3-1=11$;

$F_{k p}(3 ; 11)=3.59$

That is, $F>F_{\mathrm{kp}}$, so the coefficient of determination is statistically significant.

To assess the reliability of the obtained results, a number of additional calculations were performed, in particular, a multicollinearity analysis, which made it possible to build a regression model on a standard scale (Table 3).

Table 3. Correlation matrix

\begin{tabular}{l|c|c|c|c} 
& & \multicolumn{4}{c}{ Source: Authors' elaboration. } \\
\hline Indicators & $\mathbf{y}$ & $x_{1}$ & $x_{2}$ & $x_{3}$ \\
\hline$y$ & 1 & - & - & - \\
\hdashline$x_{1}$ & 0.3038 & 1 & - & - \\
\hdashline$x_{2}$ & 0.6829 & 0.8234 & 1 & - \\
\hdashline$x_{3}$ & 0.6017 & 0.8624 & 0.9857 & 1 \\
\hline
\end{tabular}

If the matrix has an inter factor correlation coefficient $r x_{i} x_{i}>0.7$, then there is multicollinearity in the multiple regression model. In this case, according to Table 4, $r\left(x_{1} x_{2}\right), r\left(x_{1} x_{3}\right)$, and $r\left(x_{2} x_{3}\right)$ have $|r|>0.7$, which indicates the presence of multicollinearity of the factors and the need to exclude one of them from further analysis.

The partial $F_{x}$-criterion was used to determine the redundant criterion. The calculation results are presented in Table 4. 
Table 4. Comparison of partial $F_{x}$-criteria of the regression equation

Source: Authors' elaboration.

\begin{tabular}{l|c:c:c:c}
\hline Criterion & $\mathbf{F}_{\mathbf{x i}}$ & $\boldsymbol{R}^{\mathbf{2}}$ & $\mathbf{F}_{\mathrm{kp}}$ & \\
\hline$x_{1}$ & -6.757 & 0.892 & 3.98 & $F_{\mathrm{x} 1}<F_{\mathrm{kp}}$ \\
\hdashline$x_{2}$ & 70.635 & -1.077 & 3.98 & $F_{x 2}>F_{\mathrm{kp}}$ \\
\hdashline$x_{3}$ & -35.574 & 1.625 & 3.98 & $F_{x 3}<F_{\mathrm{kp}}$ \\
\hline
\end{tabular}

According to the above calculations:

- criteria $x_{1}$ (annual interest rate on loans to individuals) and $x_{3}$ (annual household income) should be excluded from the model;

- criterion $x_{2}$ should be included in the model.

The regression analysis showed a relationship between household demand for loanable funds and GDP and confirmed the inaccuracy of the hypotheses that interest rate levels and/or household income levels have a statistically significant impact on the volume of demand for retail loans.

\section{DISCUSSION}

Discussion among scientists in the field of household debt has revealed that researchers do not pay much attention to multivariate approaches to quantitative analysis of trends in credit demand. Under the faster changes conditions, it is more important to quickly take information about the market situation. And now there is no time to conduct deep research. To solve this problem, it is necessary to use more accessible methods of trend analysis.

This paper has proved the possibility of using technical analysis methods to assess the quantitative trends of the consumer lending market. Using such an approach, banks and non-banking financial institutions can identify market signals quickly without any emotion. The obtained results give reason to assert that in the period 2008-2018 there was a lateral (flat) trend in the retail bank lending market, which is characterized by natural fluctuations within a narrow horizontal corridor. This period's minimum values lie within a corridor line that runs along the points of the respective market size values for 2009 and 2015. Based on this, suppose that the Ukrainian retail lending market is characterized by the presence of a certain psychological limit to market size drops - during recessionary periods, the market size never drops below approximately UAH 50,000 million. This volume of personal loans can be taken as the point of market support that determines the historical minimum level of household credit demand. Thus, there is a basis to assert that during hypothetical future market downturns, household's credit demand is unlikely to fall below UAH 50,000 million per year even under highly adverse conditions.

Unlike main researchers, whose starting point is to identify the stages of the economic cycle in the credit market, the main purpose of this paper is to identify the quantitative signals of the credit market. When realizing this goal, it was found that the economic crises of 2008-2009 and 2013-2015 did not affect the Ukrainian retail lending market in a fundamental manner, since they did not lead to a steady reversal of the prevailing market trend but rather only resulted in temporary, short-term adjustments. This indicates a high level of overall market stability. That is, on the balance of things, the drivers of household demand for short-, medium- and long-term loans have a strong stabilizing effect on the consumer lending market.

Demand for consumer loans is dictated by the households' varying needs, which, in turn, determine the repayment periods of loans utilized. Changes in macroeconomic conditions lead to changes in demand for certain types of loans depending on their repayment period. According to the calculated data, it can be argued that the size of short-term loans is an indicative element of the overall demand for credit. In other words, the demand for short-term loans sets the trend for the overall demand for credit of all repayment periods. Medium-term loans can make the trend more or less pronounced, depending on the analysis period. Long-term loans do not affect trend fluctuations, as their size has remained relatively stable over a fairly long period.

The study has shown that there is a close inverse relationship between the rate of change in GDP and household credit demand. This conclusion is also confirmed by the results of Eggertsson and Krugman (2012), Kim (2016), Korinek and Simsek (2016). 


\section{CONCLUSION}

The paper is aimed at identifying the main trends in the households' credit demand in Ukraine, determining the fixed components of demand and assessing the factors influencing the formation of its variable components. In accordance with the purpose of the study, one can conclude that the households' credit demand in Ukraine was not stable over the last 15 years. It decreased during economic downturns and increased during the subsequent recovery periods. The absolute size of Ukraine's GDP and the GDP growth rate dynamics are the main factors influencing the borrowing decisions of Ukrainian households. However, the cost of debt capital (expressed in the form of interest rates) does not affect the said decisions.

Within the structure of the household loan portfolio, in $66.67 \%$ of cases, medium-term loans prevailed (with a payment period between 1 and 5 years). Short-term loans accounted for $26.67 \%$ of the loan portfolio in total for the 2005-2019 period. The smallest share was represented by long-term loans, with 2008 being the sole year when they were predominant in the structure of the household loan portfolio. However, trend analysis indicates that short-term loans are a main identifier of the general market trend. Such loans are quite dynamic and largely depend on macroeconomic conditions, generating market movements. If the relevant direction is supported by medium-term loans, the general market trend will be in line with the GDP growth trend. At the same time, the demand for long-term loans is quite inertial; changes in it do not affect the overall market trend. Demand for long-term loans is a constant element of Ukrainian households' aggregate demand for credits. This element of aggregate demand for credits peaked in 2008.

Given the general market trends and the preferences of households in choosing the maturity structure of loans, it can be assumed that the market will not be able to return to such peak values during the next major trend (within the next 10 years). The analysis of historical market lows shows that even under highly adverse market conditions arising from the accumulations of negative exogenous factors, household's credit demand in Ukraine does not fall below UAH 50 million. This value is defined as the market support limit and can be used in pessimistic scenarios of the retail lending market development.

\section{AUTHOR CONTRIBUTIONS}

Conceptualization: Rostyslav Slav'yuk.

Data curation: Lyudmyla Shkvarchuk.

Formal analysis: Rostyslav Slav'yuk.

Funding acquisition: Lyudmyla Shkvarchuk.

Methodology: Lyudmyla Shkvarchuk.

Project administration: Rostyslav Slav'yuk.

Resources: Rostyslav Slav'yuk.

Software: Lyudmyla Shkvarchuk.

Validation: Rostyslav Slav'yuk.

Writing - reviewing \& editing: Lyudmyla Shkvarchuk.

\section{REFERENCES}

1. Alter, A., Feng, A. X., \& Valckx, N. (2018). Understanding the Macro-Financial Effects of Household Debt: A Global Perspective (IMF Working Paper No. 18/76). Retrieved from https:// www.imf.org/en/Publications/ WP/Issues/2018/04/06/Understanding-the-Macro-Financial-
Effects-of-Household-Debt-AGlobal-Perspective-45744

2. Brillinger, D. R. (1995). Trend analysis: binary-valued and point cases. Stochastic Hydrology and Hydraulics, 9, 207-213. Retrieved from https://link.springer.com/ article/10.1007\%2FBF01581719
3. Cherkasova, S., Kalaitan, T., Rushchyshyn, N., Yaremko, I., \& Yaroshevych, N. (2020). Stimulating and limiting factors for the growth of investment potential of Ukrainian insurance companies. Investment Management and Financial Innovations, 17(1), 85-96. http://dx.doi.org/10.21511/ imfi.17(1).2020.08 
4. Chudik, A., Mohaddes, K., Pesaran, M. H., \& Raissi, M. (2015). Is There a Debt-threshold Effect on Output Growth? (IMF Working Paper No. WP/15/197). Retrieved from https:// www.imf.org/external/pubs/ft/ wp/2015/wp15197.pdf

5. Cuzick, J. (1988). Trend tests. In Encyclopedia of Statistical Sciences (pp. 336-342). Wiley-Interscience.

6. Cynamon, B. Z., \& Fazzari, S M. (2008). Household debt in the consumer age: source of growth - risk of collapse. Capitalism and Society, 3(2), 3. https://doi. org/10.2202/1932-0213.1037

7. Dejuán, D. (2017). The dynamics of household debt and GDP: Reconsidering Minsky from an empirical perspective (US, 1980-2016). In XXIV Encuentro de Economía Pública (pp. 87-164). Universidad de Castilla-La Mancha. Retrieved from https://dialnet.unirioja.es/servlet/ articulo? codigo $=6121557$

8. Du, R. Y., \& Kamakura, W. A (2012). Quantitative Trendspotting. Journal of Marketing Research, XLIX, 514-536. Retrieved from https:// www.bauer.uh.edu/rexdu/quantitative\%20trendspotting.pdf

9. Duygan-Bump, B., \& Grant, C. (2008). Household debt repayment behaviour: what role do institutions play? (Working Paper No. QAU083). Federal Reserve Bank of Boston. Retrieved from https://ideas.repec. org/p/fip/fedbqu/qau08-3.html

10. Eggertsson, G. B., \& Krugman, P. (2012). Debt, Deleveraging, and the Liquidity Trap: A Fisher-MinskyKoo Approach. Quarterly Journal of Economics, 127(3), 1469-1513. https://doi.org/10.1093/qje/qjs023

11. Glick, R., \& Lansing, K. J. (2010). Global household leverage, house prices, and consumption. FRBSF Economic Letter, 1, 1-5. Retrieved from https://www.frbsf.org/economic-research/files/el2010-01.pdf

12. Greben, J. M. (2007). A theory of quantitative trend analysis and its application to South African general elections. South African Journal of Science, 103(5-5), 232-238. Retrieved from http://www.scielo.org. za/pdf/sajs/v103n5-6/15.pdf

13. Juárez, C. F. (2015). The Credit Behavior of Households - A Behavioral
Approach. http://dx.doi.org/10.2139/ ssrn. 2440723

14. Kane, A. (2020). Secteurimmobilier et asymmetries macroéconomiques (Ph.D. Thesis). Université de Sherbrooke. (In French). Retrieved from https://savoirs.usherbrooke. ca/bitstream/handle/11143/17729/ Kane_Aminata_PhD_2020. pdf? sequence $=1$ \&isAllowed $=y$

15. Kannadas, S. (2021). Investment behavior of short-term versus longterm individual investors of PAN India - An empirical study. Investment Management and Financial Innovations, 18(2), 223-233. http://dx.doi. org/10.21511/imfi.18(2).2021.18

16. Kim, Y. K. (2016). Macroeconomic effects of household debt: an empirical analysis. Review of Keynesian Economics, 4(2), 127-150. https://doi. org/10.4337/roke.2016.02.01

17. Korinek, A., \& Simsek, A. (2016). Liquidity Trap and Excessive Leverage. American Economic Review, 106(3), 699-738. https://doi. org/10.1257/aer.20140289

18. L'opez-Salido, D., Stein, J. C., \& Zakraj`sek, E. (2017). Credit-Market Sentiment and the Business Cycle. The Quarterly Journal of Economics, 132(3), 1373-1426. https://doi. org/10.1093/qje/qjx014

19. Landau, E. (2020). The Fibonacci Sequence Is Everywhere - Even the Troubled Stock Market. Smithsonian Magazine. Retrieved from https:// www.smithsonianmag.com/sciencenature/fibonacci-sequence-stockmarket-180974487/

20. Lombardi, M., Mohanty, M., \& Shim, I. (2017). The real effects of household debt in the short and long run (BIS Working Papers No. 607). Retrieved from https://www.bis.org/ publ/work607.pdf

21. LvGanga, Yu, B., Chen, Z., Zhou, Z., \& Shi, Y. (2012). The Analysis of Peasant Household's Credit Behaviour. Procedia Computer Science, 9, 1228-1233. https://doi.org/10.1016/j. procs.2012.04.133

22. Mian, A., \& Sufi, A. (2010). Household leverage and the recession of 2007 to 2009. IMF Economic Review, 58(1), 74-117. Retrieved from https://www.jstor.org/stable/25762071
23. Mian, S., Sufi, A., \& Verner, E. (2017). Household Debt and Business Cycles Worldwide. Quarterly Journal of Economics, 132(4), 17551817.

24. Palley, T. I. (1994). Debt, aggregate demand, and the business cycle: an analysis in the spirit of Kaldor and Minsky. Journal of Post Keynesian Economics, 16(3), 371-390. https:// doi.org/10.1080/01603477.1994.11 489991

25. Pelzer, B., Eisinga, R., \& Franses, P. H. (2001). Estimating transition probabilities from a time series of independent cross sections. Statistica Neerlandica, 55(2), 249262. https://doi.org/10.1111/14679574.00168

26. Sági, J., Chandler, N., \& Lentner, C. (2020). Family businesses and predictability of financial strength: a Hungarian study. Problems and Perspectives in Management, 18(2), 476-489. http://dx.doi.org/10.21511/ ppm.18(2).2020.39

27. Santos, A. C., Costa, V., \& Teles, N. (2014). The Political Economy of Consumption and Household Debt: An Interdisciplinary Contribution. RCCS Annual Review A selection from the Portuguese Journal Revista Crítica de Ciências Sociais, 6. http:// doi.org/10.4000/rccsar.537

28. Shkvarchuk, L., \& Slav'yuk, R (2019). The Financial Behavior of Households in Ukraine. Journal of Competitiveness, 11(2), 144159. https://doi.org/10.7441/ joc.2019.03.09

29. Villez, K. (2014). Qualitative trend analysis for process monitoring and supervision based on likelihood optimization: state-of-the-art and current limitations. IFAC Proceedings Volumes, 47(3), 7140-7145. https://doi.org/10.3182/20140824-6ZA-1003.01596

30. Zakaria, R. H., Jaafar, N., \& Ishak, N. A. (2017). Household debt decision: poverty or psychology? International Journal of Business and Society, 18(3), 515-532. Retrieved from http://www.ijbs.unimas.my/ images/repository/pdf/Vol18-no3paper8.pdf

31. Zinman, J. (2014). Household Debt: Facts, Puzzles, Theories, and Policies (NBER Working Paper No. 20496). http://doi.org/10.3386/w20496 